\title{
Digital Finance For Improving Financial Inclusion Indonesians' Banking
}

\author{
Estu Widarwati ${ }^{1 *}$, Asep Solihin ${ }^{2}$, Nunik Nurmalasari ${ }^{3}$ \\ 1, 2, 3STIE Sutaatmadja, Indonesia \\ E-mail: 1'wie2tdz@gmail.com, 2asep.sholihin11@gmail.com, ${ }^{3}$ nuniknurmalasari90@gmail.com \\ *Corresponding author
}

\section{JEL Classification:}

E50

E58

G21

G28

Received: 23 October 2020

First revision: 27 January 2021

Second revision: 09 April 2021

Accepted: 27 April 2021

\begin{abstract}
A digital finance service breakthrough is essential to get better financial assistance to optimize financial inclusion, and the effectiveness requires technological support in banking financial services. The study investigates the effect of digital finance on financial inclusion in Indonesians' banking industry. We develop the new measurement, namely average digital finance (ADF), and use loan transactions to proxy financial inclusion. The samples are six banking during 2013-2019, and we use panel data regression to test the hypothesis and do a robustness check. Our result confirms that ADF positively impacts financial inclusion and finds evidence of bank size's role in digital finance and financial inclusion. It implicates banks' strategy for optimizing financial inclusion based on its characteristics such as age, profitability, and efficiency. It contributes to digital finance's government policy for using explored internet banking and mobile banking stimulatingly.
\end{abstract}

\section{Keywords:}

financial services, digital finance, mobile banking, internet banking, financial inclusion

How to Cite:

Widarwati, E., Solihin, A., \& Nurmalasari, (2022). Digital Finance For Improving Financial Inclusion Indonesians' Banking. Signifikan: Jurnal Ilmu Ekonomi, 11(1), 17-30. https://doi.org/10.15408/sjie.v11i1.17884. 


\section{INTRODUCTION}

The issue of financial inclusion globally is essentially a worldwide government concern. The lack of opportunities to access financial services by vulnerable and needy groups is a global policy problem. Finding an innovative financial service model for the poor is an urgent challenge. It is based on the argument that poverty is a money gap and a gap in access to financial instruments that can improve lives. This financial limitation can slow economic growth and exacerbate economic inequality (Demirguc-Kunt et al., 2008). Therefore, the G-20 and the World Bank are trying to reduce poverty levels in developing countries through increased financial inclusion (GPFI, 2011; Ozili, 2018).

Financial inclusion has been a central policy government of many developing and emerging countries. Sahay et al. (2015) state that financial inclusion as the use of, and access to, legal, financial services will bring the excluded population access to formal financial products and services. Financial inclusion is expected to alleviate poverty and minimize a country's economic gap. Financial inclusion engenders aggregate Gross Domestic Product (Dabla-Norris et al., 2015). The unequal access to public finance due to the distribution of residences far from financial service centers has encouraged the importance of banks' role in strengthening financial inclusion strategies. The well-managed, efficient and inclusive financial system will improve an individual's financial state, provide facilities for goods and services exchange, integrate between society and economy, and protect economic shocks. There are many successes of financial inclusion stores such as India (Chavan et al., 2009), Zimbabwe (Mago \& Chitokwindo, 2014), Nigeria (DavidWest et al., 2018), also Somalia and Kenya (Gas, 2019).

Financial inclusion is still a relevant issue for many countries that drive some innovation of financial institutions. Technological development leads to a fundamental re-imagining process and business capital in the financial services industry (World Bank Group, 2016). The increase in the internet-based economy using digital, especially mobile media, has led to financial transaction development structure changes. Digital Financial Services (DFS) have become a fundamental part of everyday life for every individual. Digital Financial Services provides the means to meet these needs and can give an excellent contribution to national economies' growth. Digital finance leads to digitalization, including all electronic products and financial sector services such as credit, electronic exchange systems, and home banking.

Furthermore, digital finance provides access to banks and their services, such as payment systems and credit that otherwise could hardly be reached (Gomber et al., 2017). The financial inclusion of digital finance has been internationally regarded as a means of adequate to provide opportunities to promote financial inclusion by reducing financial services costs (Asian Development Bank, 2016). Bank directs services into the banking network through various bank products accessible and affordable to the lowincome earners as one of the financial institutions.

Financial inclusion becomes a significant driver of poverty because low-income people can now enjoy financial service through increased economic growth (Mago 
\& Chitokwindo, 2014). Some countries show significant progress in their banking management. Raj (2015) explains that some African States have progressed rapidly in monetary consideration by utilizing computerized financial control over the past few years. In Kenya, digital financial services have become a solution for addressing economic difficulties. It is reflected by the growing amount of credit in Kenya banking. David-West et al. (2018) describe financial technology in Nigeria to impact sustainable economic growth positively and have great potential for financial inclusion.

In Indonesia, the financial inclusion trend began to emerge after the monetary crisis in 2008, based primarily on crisis impact to the groups of bottom pyramids such as labor, low-income earners, and nonpermanent residents who have not accessed banking services (Bank Indonesia, 2016). Maverick's Indonesia reported that the banking industry increasingly adopted the newly emerging digital trend in 2018. Banking is actively launching digital services products, either independently or collaborating with financial technology (fintech) companies. Digital Financial Services (DFS) that have evolved in Indonesia are internet banking, mobile banking, and e-Money. According to Bank Indonesia (2016), the principles in DFS emphasize the right balance between innovation and risk in achieving greater financial inclusion and utilization of legal and regulatory frameworks for using digital technology to improve financial inclusion. It involves establishing a digital financial practice responsible for protecting consumers and improving financial literacy and awareness to understand digital financial products better.

Implementation of inclusive financial policy in Indonesia is very relevant to support Bank Indonesia's effectiveness and monetary function, payment system, and financial system stability. Inclusive finance helps lower liquidity pressure and credit risk in the banking sector. Furthermore, inclusive finance enables opening new retail markets, especially micro and small credit, diversifying portfolios, and minimizing credit risk. The inclusive economic program can also improve community capabilities and responsible finance through financial education and consumer protection. Generally, an inclusive financial policy can increase the effectiveness of existing monetary policy to touch all life walks (Bank Indonesia, 2016).

Banks have a significant role as financial service providers to encourage financial inclusion in Indonesia. Financial services of digital technology have become a new alternative in providing financial access services to the community. Banking financial services technology will help reach the community, especially rural communities that are generally not affordable by banks. The fact of Indonesia shows that the financial access conditions are assessed still low that reflected in the financial inclusion index Peruta (2015) finds that Indonesia is rank 9 (nine) of Index of Financial Inclusion (IFI). Moreover, part of cluster 2 (two) is defined as the group of countries that have been implemented for a short time (just below two years). Indonesia's financial inclusion experienced a growth of $12.8 \%$ compared to the survey results in 2014 , which amounted to $36.1 \%$. It means that the account growth amounted to $4.2 \%$ per year. The last survey conducted by the World Bank in 2017 showed that Indonesia's financial inclusion was 48,9\% of the adult population already had an account. It can interpret that from 100 Indonesian adult residents, only 49 
people have accounts with formal financial institutions. Although Bank Indonesia's data for 2020 shows that the trend of financial and digital economic transactions is growing positively, the volume of digital banking transactions has increased from 2017 to 2019, with an average growth of $21.13 \%$ (Warjiyo, 2021). However, general solid preferences and acceptance are needed for the successful Bank's role in facilitating access to financial services. This fact is in line with banks' role in Kenya, ensuring sustainability reaching people who do not have a bank account and driving inclusive financial growth (Kithinji, 2017). A similar thing is stated in Ozili (2018) found that digital finance through financial technology services affects financial inclusion in developing and advanced countries and digital finance convenience for low-income individuals.

However, the effectiveness of financial inclusion requires technological support in the application of banking financial services. A breakthrough in digital finance service is essential for better financial services to optimize financial inclusion. The innovation of financial institutions needed in many ways includes mobile banking concepts reached by 'unbanked' low-income earners and the unemployed as long as they have access to a cell phone (Mago \& Chitokwindo, 2014). It is made possible through digitization, which can essentially turn a smartphone into a wallet, cheque book, bank branch, and accounting ledger, all in just one service. Digital finance refers to financial services providers who use portable or mobile technologies and web technologies, and network agents to conduct processing and supervision of their financial services.

Access to financial services brings so many benefits to society through digital financial innovations that affect banking institutions' performance and improve access to financial services. Theoretically, financial innovations show that digital financial innovations enhance financial inclusion, while the technology acceptance model indicates that acceptance of DFS improves financial services accessibility by various users. Mobile banking has benefited multiple stakeholders, such as increasing the flow of money, spreading entrepreneurship, and increasing Gross Domestic Product (Singh et al., 2014). The finding of Salam (2018) in Indonesia stated that digital banking is beneficial and helps Sharia bank services. Kithinji's research (2017) in Kenya also finds the significant impact of digital banking strategy in improving the Bank's financial inclusion.

The importance of mobile technology in expanding financial services at an affordable cost is due to the initial investment and other fixed expenses, so the marginal cost is very low for every transaction or every new customer (Honohan \& Beck, 2007). It has rapidly led to mobile money expansion and helped infrastructure constraints and inclusive finance (Son et al., 2020). The development of mobile financial service in emerging and developing countries are primarily equipped with a mobile phone that provides an advantage in terms of access to financial assistance. Hopefully, through internet banking and mobile banking, financial services will encourage the public to easily make financial transactions and improve banking services quality (Peruta, 2015). Furthermore, the community is more accessible in conducting banking services through mobile money such as credit submission that can improve productivity by increasing efficiency, lowering the transaction cost, and creating a platform for other businesses (Donovan, 2011). 
Providers of digital finance services are profit-seeking corporations that use digital finance to maximize their profitability or maximize the profitable opportunities of businesses affiliated with digital finance providers, namely banks' financial and nonfinancial institutions. However, on the other side, there are obstacles to implementing digital services, such as costly costs and risks, unavailability of extensive infrastructure, and banking crimes committed by the user. The expected benefit of digital finance for improving financial inclusion can only be fully realized if the cost of providing digital financial services is negligible or zero (Ozili, 2017). The failure of digital finance can be triggered by the inaccuracy of the applied digital finance technology such as mobile finance (credit, insurance, and savings), mobile banking (transactional and informational), and mobile payment (P2P, G2P, and B2B). Because it also depends on the level of financial literation in the community (Donovan, 2011). Mobile banking is a mobile technology to access banking services run by banks or other financial institutions and allows customers access to their bank accounts using mobile technology (Ahmad et al., 2020). The number of mobile banking transactions can raise costs and risk of crime in the community's low financial literacy and decrease financial inclusion. Therefore, it needed to study the process of mobile banking by banks and customers (Singh et al., 2014).

The number of studies examining digital finance's financial inclusion effect from a banking perspective is still relatively small and limited. That makes us look for banks' role in digital finance and their impact on financial inclusion, especially in Indonesia. Some previous research such as Chavan et al. (2009), Mago \& Chitokwindo (2014), (Peruta, 2015), and Son et al. (2020), tend to analyze digital finance and financial inclusion from the users perspective and explore the advantage of digital finance in improving users welfare by increasing financial services access. As part of the financial system, we argue that banks urgently provide digital financial services through mobile money for various users. It is expected to increase poverty and become a solution to overall economic improvement for the country.

The form of fintech innovation enables financial transactions through mobile devices (Donovan, 2011). Mobile money shares other technical design characteristics, such as mobile payments and online banking (Senyo \& Osabutey, 2020). Then we use bank transactions through mobile technology as a proxy of digital finance because it reflects account ownership by users, transaction costs of the Bank, and financial transactions that led to the level of competition of digital services. Precisely, we capture the digital finance of the Bank through internet banking and mobile banking transactions based on the argument. The high and low commerce of the two shows that individual customers' perceptions and attitudes are either positive or negative on banks' digital financial services (Singh et al., 2014). Analysis bank as economic digitalization services intermediator is essential for deciding the level of trust. In mobile money services through the story of mobile transactions.

Internet banking and mobile banking are part of digital finance, namely digital finance business function, relevant technologies, technological concepts, and institutions providing digital finance solutions, i.e., Bank (Gomber et al., 2017). This study develops the new digital finance measurement, namely Average Digital Finance (ADF), consisting 
of the average sum of internet and mobile banking. This ADF measurement developed from previous research of Kithinji (2017) that uses the internet and mobile banking as two separated proxies of digital finance. We argue that combining mobile money types in one measurement will better reflect digital finance's function. Singh et al. (2014) state that product usage-controlled by individuals' thinking and perception about digital financial services, leading to the perception that is increasing various mobile transactions will reflect users' positive perception in adopting digital finance.

Furthermore, our study uses the number of loans as a proxy of financial inclusion based on financial inclusion arguments that reduce poverty by creating productivity due to easy access to users' formal financial services. Being an owner of mobile money accounts such as the internet and mobile banking increases the probability of saving and loantaking behavior (Gas, 2019). The high loans reflect users' capability to improve their well-being by providing education, medical, farm or business, and others.

Therefore, this study analyzes digital finance's impact on the banking industry's financial inclusion in Indonesia during 2013-2019. The research formulates problems related to digital finance's influence on financial inclusion. It is expected to have the practical implication that the banking industry can consider digital finance aspects as a strategic decision for designing financial service through financial inclusion policy based on bank characteristics. Furthermore, this research is also expected to reference the government's consideration of financial inclusion strategy through digitalization banking services according to the community's features.

\section{METHODS}

This study investigates the impact of digital finance and financial inclusion in Indonesia. We hypothesize that digital finance has a positive effect on increasing financial inclusion. We explore yearly data from the banking industry from the Indonesia Stock Exchange (IDX) and Authority Financial Services (OJK) from 2013 to 2019. Analyzed data by assessing and deepening the literature relating to research, online searching, and other websites linked to data needs. Our sample based on internet banking and mobile banking transactions is 6 (six) Bank Central Asia, Bank Rakyat Indonesia, Bank Tabungan Negara, Bank Mandiri, Bank Nasional Indonesia, and Bank CIMB Niaga. We exclude bank mergers or acquisitions and incomplete data for variables.

Our study focuses on analyzing the role of banks in digital finance and financial inclusion, so we select the relevant measurement of bank financial reports' variables. This research's dependent variables are financial inclusion proxied by the loans, and the independent variable are internet banking and mobile banking as digital finance proxies. We developed a new digital finance measurement, namely Average Digital Finance (ADF), measured by the average of internet and mobile banking transactions. It is based on the argument that merging it more reflects all value of digital finance, according to Singh et al. (2014). We also use control variables in this study bank: bank profitability measured by net income margin, bank efficiency ratio based on operating cost to operating income, and bank age. 
This study tested the hypotheses that examine the impact of digital finance on financial inclusion, and we built the empirical model are formulated as follows: According to this, the model estimate in this study is as follows:

$$
\mathrm{LOAN}_{\mathrm{it}}=\beta_{0}+\beta_{1} \mathrm{ADF}_{\mathrm{it}}+\beta_{2} \mathrm{PROF}_{\mathrm{it}}+\beta_{3} \mathrm{EFR}_{\mathrm{it}}+\beta_{4} \mathrm{AGE}_{\mathrm{it}}+\mathrm{e}_{\mathrm{it}}
$$

Where: it represents Bank and time; respectively, LOAN is financial inclusion proxied by loans. ADF is the Average of Digital Finance proxied by the average sum of internet and mobile banking transactions. PROF is bank profitability measured by Net Interest Margin, EFR is bank efficiency ratio measured by Operating Cost to Operating Income, and AGE is bank age.

Furthermore, the study used panel data regression to estimate cross-section and time-series data parameter estimation. The regression method data panel will give the estimation result, which is Best Linear Unbiased Estimation (BLUE). Estimating the regression model using panel data can be done through three approaches: standard effect model, fixed-effect model, and random effect model. In this study, we use the random effect model based on the argument it can describe a random character of the $\mathrm{i}$-th unit observation and remains at all times. We also did the robustness check by replacing the independent variable following Kithinji (2017) that uses the internet and mobile banking as two independent digital finance measurements.

\section{RESULT AND DISCUSSION \\ Descriptive Statistical Analysis}

Digital finance requires extensive infrastructure, which can be done more freely by giant Bank's assets. Descriptive data shows that the highest average of mobile banking transactions is 1318 million transactions, BCA Bank, while the lowest trade value is 14,35 million is BTN bank. The highest value of Internet banking transactions is 1711 million is also a BCA bank, whereas the most inadequate marketing is BTN Bank is 1,1 million. Furthermore, the highest is BRI Bank for the credit value found, and the lowest is BTN Bank. The highest efficiency ratio of Bank measured by Operating Cost to Operating Income is BTN bank, and the highest profitability of Bank proxied by Net Interest Income (NIM) is BRI bank. Furthermore, Table 1 shows more extensive Banks having more mobile and internet banking transactions than smaller ones.

Table 1. The Descriptive Statistical Analysis

\begin{tabular}{lccccccc}
\hline & $\begin{array}{c}\text { LOANS } \\
\text { (in a million } \\
\text { Rp) }\end{array}$ & $\begin{array}{c}\text { MBANK } \\
\text { (in a million } \\
\text { transaction) }\end{array}$ & $\begin{array}{c}\text { IBANK } \\
\text { (in a million } \\
\text { transaction) }\end{array}$ & $\begin{array}{c}\text { ASSETS } \\
\text { (in a million } \\
\text { Rp) }\end{array}$ & $\begin{array}{c}\text { PROFITABILITY } \\
\text { (Net Interest } \\
\text { Margin) }\end{array}$ & $\begin{array}{c}\text { EFFICIENCY } \\
\text { (Operating Cost to } \\
\text { Operating Income) }\end{array}$ & AGE \\
\hline Mean & 418000 & 457 & 449 & 636000000 & 0,060 & 0,719 & 75 \\
Median & 405000 & 257 & 30 & 615000000 & 0,058 & 0,702 & 66 \\
Maximum & 970000 & 3850 & 2510 & 1420000000 & 0,086 & 0,981 & 124 \\
Minimum & 92400 & 2,1 & 0,2 & 131000000 & 0,033 & 0,062 & 15 \\
Std. Dev. & 235000 & 694 & 677 & 366000000 & 0,011 & 0,148 & 36 \\
Skewness & 0,491 & 3,20 & 1,684 & 0,365 & 0,483 & $-1,822$ & $-0,01$ \\
\hline
\end{tabular}

Source: Authors' data (2020) 
As reflected in the number of mobile and internet banking transactions, digital banking development increased during 2013-2019. It is in line with Bank Indonesia data (2020), which states that digital banking transactions have grown significantly since 2016-2019 due to the positive attitude of public acceptance of digital financial services. Figure 1 shows that the growth of internet banking is higher than mobile banking, which leads to an increase in financial literacy, especially digital finance among Indonesians, which provides a better understanding of the benefits of mobile money in supporting their activities. Good knowledge of digital financial services encourages increased public trust as digital technology users in banking products improve the quality of life and economic welfare.

Figure 1. Development of Digital Banking Transactions in Indonesia 2013-2019

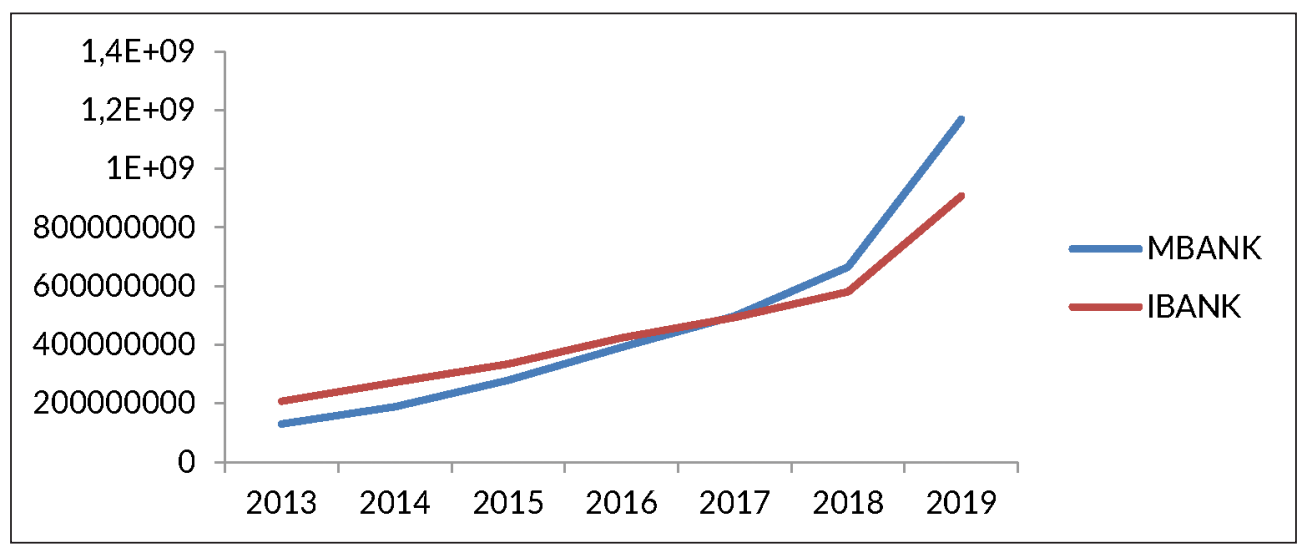

Source: Authors' data (2020)

Overall, the proportion of the number of digital financial service transactions was dominated by private banks, which reached $58 \%$, while the accumulation of digital banking transactions by state banks was only $42 \%$ (see Figure 2 ). The flexibility of the digital finance strategy by private banks greater than government banks is possible because the ownership structure determines the Bank's strategic decisions and capacity. In line with Honohan \& Beck's (2007) findings, the influence of ownership structure depends on the strategies and capabilities of the resulting bank management. The Bank has unique characteristics, such as age, size, ownership, and boards. Then it may be linked to the decisions making.

Figure 2. The Proportion of the number of Digital Banking transactions in Indonesia 2013-2019

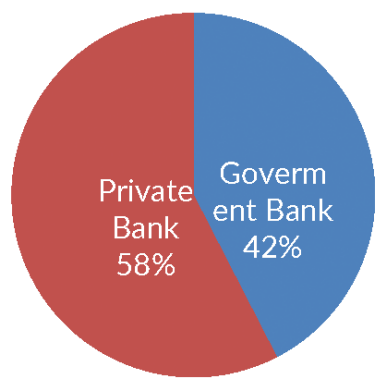

Source: Authors' data (2020) 
Private banks have independent capital management to develop digital finance strategies for improving market share and applied technology financial inclusion. For handling bank characteristics gap, certain functions can be divided so that each Bank can achieve economies of scale. The collaboration between state and private banks needs to be improved. There is a unity of perception regarding digital financial services standards with each function's division based on the coverage area of digital financial services, both urban and rural. It is intended to achieve economies of scale from each of its digital banking strategies.

Figure 3. Effectiveness of Digital Banking in Indonesia 2013-2019

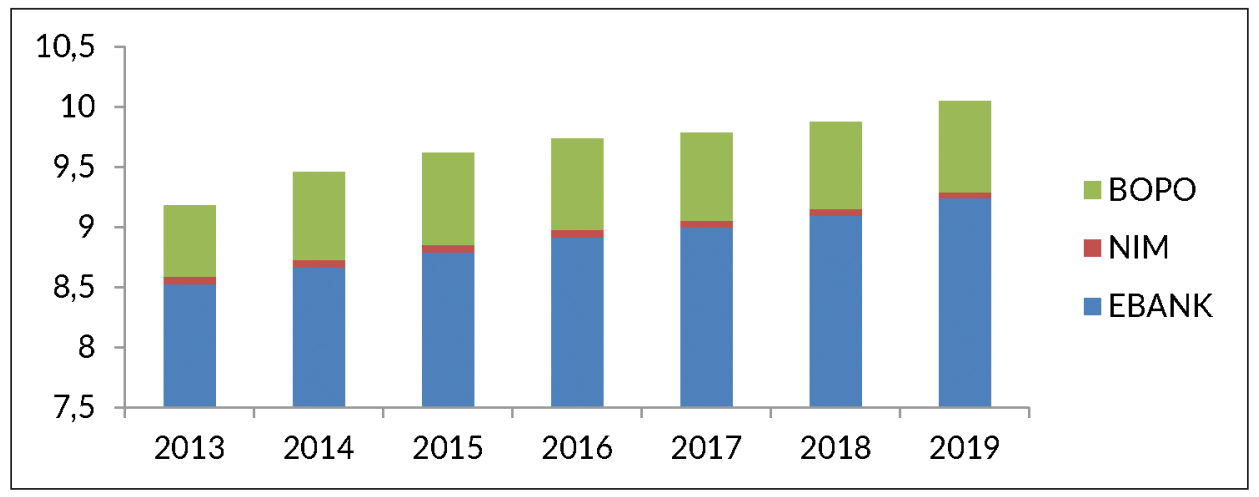

Source: Authors' data (2020)

Furthermore, digital finance's effectiveness in Indonesian banking in Figure 3 appears to be not optimal based on the size of the Net Interest Margin (NIM) and Operational Cost to Operating Income (BOPO). The increase in the number of digital banking transactions (mobile and internet banking) has boosted banking income margins, but this has not been followed by a decrease in operating costs, as shown in Figure 3.

Figure 4. Digital Finance Performance in Indonesian Banking 2013-2019

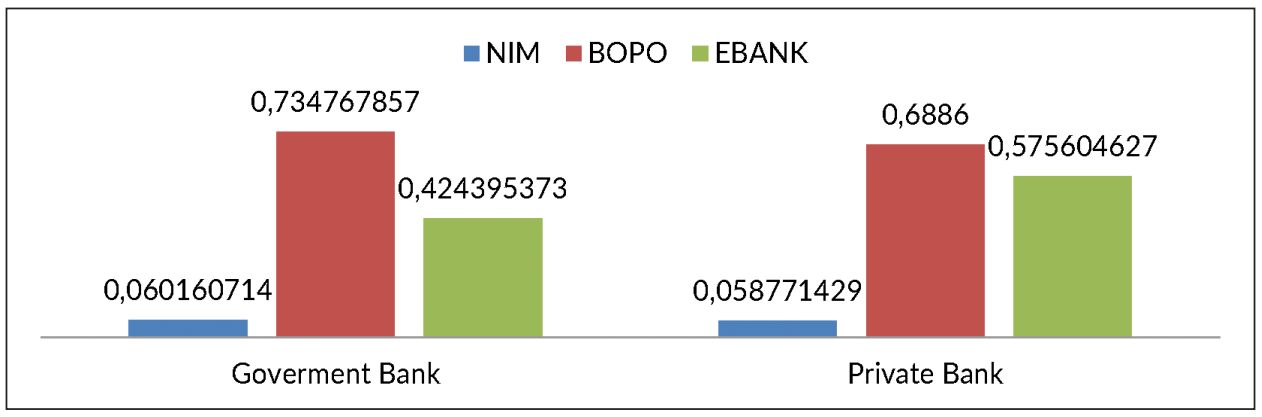

Source: Authors' data (2020)

The comparison of private and government banks' digital finance performance in Figure 4 shows that the average private bank is more efficient in providing internet and mobile banking. However, digital finance strategies for improving financial inclusion need to consider increasing profits at low prices. Although state banks have a higher average NIM than private banks, the value of government bank operational costs as 
reflected in BOPO is still high. It requires evaluation by the banking sector in Indonesia, considering that financial services technology procurement should be linked with relatively low marginal unit costs (Honohan \& Beck, 2007).

Furthermore, this study's findings show an overview of Indonesian banks' role in financial inclusion through digital finance, as shown in Figure 5. The increase in the number of digital banking transactions from 2013 to 2019 is in line with the number of loans. It can be interpreted as increasing informal access to financial services obtained by the public. Digital finance improves financial services that are more practical and easier and provides access for the unbanked community. It can also offer financial services in real-time, facilitating payments, savings, credit, insurance, and other financial facilities in banking. The number of mobile transactions shows that individual customers' perceptions and attitudes are positive or negative on banks' digital financial services (Singh et al., 2014). The positive financial experiences lead to the trust level of digital financial transactions.

Figure 5. Development of Digital Finance and Financial Inclusion in Indonesia 2013-2019

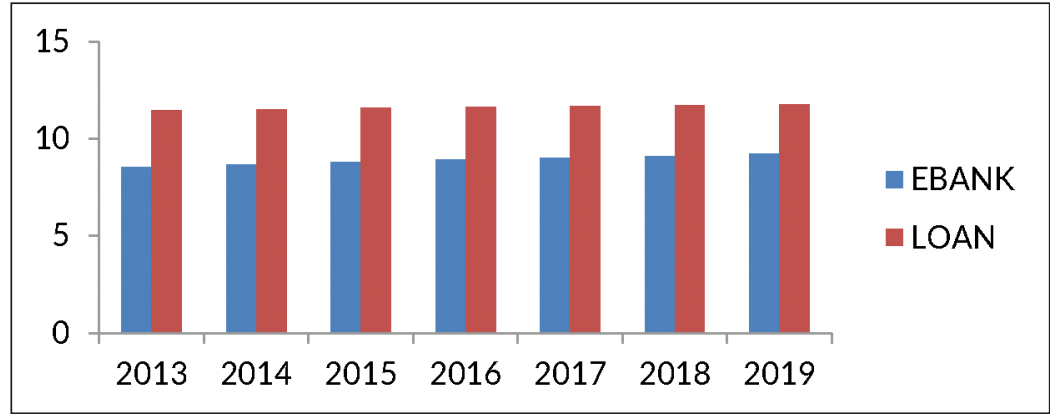

Source: Authors' data (2020)

The growth in banking financial inclusion achievements shows digital financial services' success for easy access to formal finance for the public. The increase in loans as an indicator of banking finance encourages other digital products that require anticipation from banks and the government. Banks and the government's role is also crucial because it needs to create a safe environment for these digital financial service facilities (Gabor \& Brooks, 2017). The increase of loans can lead to higher risks for the bank, namely lousy credit that will trigger distressed banks if not appropriately managed.

Gas (2019) states that financial inclusion determinants are individual characteristics such as gender, age, education, and behavior (saving and loan). The determinant of financial inclusion is the quality of digital banking implementation by financial services institutions and the user side, in this case, the community. On the bank side, financial inclusion's effectiveness through technological support should preferably be efficient risk management and financial literacy for the community. When people understand that digital finance makes access to formal financial services more manageable, their opportunities to improve their economy are open, such as school loans and medical treatment. Owning a mobile financial service account will direct their behavior to facilitate digital finance. The education process is essential for digital financial literacy for the 
community. It is the key to accelerating digital finance applications' understanding of easy access to users' financial services.

We analyze digital finance's impact on financial inclusion using panel data regression, especially cross-section random effect. As our expectation, the study results show a significant impact of digital finance on financial inclusion. Implementing a new measurement, which combines average mobile banking and internet banking, namely Average Digital Finance (ADF), has a positive coefficient in increasing loans. Our findings support Mago \& Chitokwindo's (2014) previous research that digital financial services have an urgent role in financial inclusion for increasing financial activity and boosting economic growth.

Table 2. Regression Result

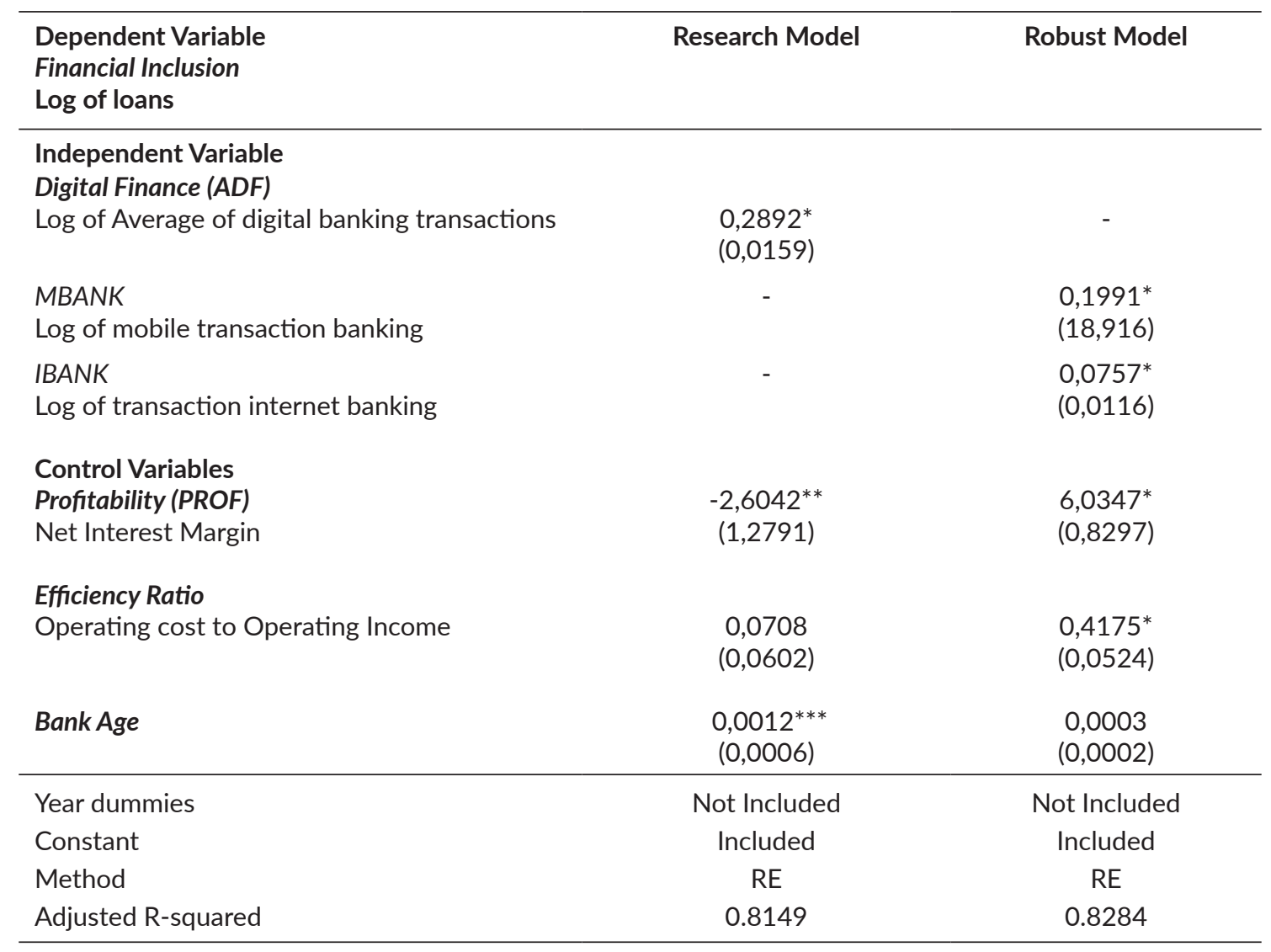

This table presents the results of random effect panel data both of research model and robust model. The dependent variable is financial inclusion provide by credit loans (LOANS); the independent variable is digital finance proxied by the average transaction of mobile banking and internet banking (ADF). In contrast, for the robust model using separated mobile banking transaction (MBANK) and internet banking transaction (IBANK). The control variables are bank profitability measured by Net Interest Margin, bank efficiency ratio in Operating Cost to Operating Income and bank age. The values in parentheses are standard errors. *significant $1 \%{ }^{* *}$ significant $5 \%{ }^{* * *}$ significant $10 \%$

In contrast, banks' increase in financial inclusion through access to loans has not always resulted in profits. Table 2 shows the finding of a negative coefficient of Net Interest Margin (NIM), which means that the increase in loans reduces the bank's income margin, which is possible due to the erosion of high bank operational costs. It is supported by the descriptive data in Graph 3, which shows that Indonesian banks' efficiency in the digital banking program has not yet been optimal, which has increased bank operational costs. 
It seems to contradict the original goal of developing digital finance to improve financial services' quality, diversity, and efficiency ( $\mathrm{Li}$ et al., 2020). The mobile banking system is ideal for remote areas, given that it is an easily accessible, cheaper, more convenient, and faster means of sending and receiving money. However, this should apply both from the perspective of users and banks as financial service intermediaries, and when banks experience inefficiency, the purpose of digital finance becomes doubtful. It is based on the statement of Sahay et al. (2015) and Dabla-Norris et al. (2015) that financial inclusion should consist of a combination of market depth (size and liquidity), efficiency (sustainable, lowcost financial services), and access (the ability of individuals to access financial services).

Furthermore, this study found evidence that age banks control the influence of digital finance on financial inclusion. It means that banks that have been engaged in the banking industry for a long time will be better able to implement digital financial services to increase financial inclusion. It is based on the logical argument that the longer a bank lasts in its industry, the better it will carry out various strategies and explore multiple digital financial services. Younger banks need more priority for determining the accuracy of digital banking due to limited experience and market share.

Furthermore, we conducted a robustness check to follow Kithinji (2017) by replacing the digital finance proxy by separating internet banking and mobile banking. As expected, mobile banking's coefficient as a measurement of digital banking is still positive for financial inclusion. Contrastly, profitability and efficiency banks proved significant control variables in digital banking and financial inclusion. This finding supports graph three's descriptive data that show increased digital finance will increase net interest margin and bank cost.

\section{CONCLUSION}

A country's economic growth achievement and financial inclusion are a solution to improving poverty by providing affordable financial services by all circles and providing good quality financial services, effective and efficient. The research results prove that digital finance positively impacts financial inclusion through digital financial services, facilitating access to financial services. The bank functions as an intermediary financial offer digital financial assistance for the public. Such as mobile banking, internet banking, and other products. The growth of digital banking transactions will trigger an increase in the financial inclusion index, which can boost banking financial stability.

Furthermore, the study results show that increasing or decreasing internet banking and mobile banking transactions can simultaneously influence credit penetration (loans). It is supported by positive public acceptance and understanding of banking digital financial literacy. It has implications for Indonesia's banking strategy to improve further the education and socialization of digital banking financial services. Banks should explore digital technology in financial assistance based on characteristics such as costs, benefits, and age. Thus, increasing financial inclusion through digital finance will be optimal and not reduce bank revenues, reducing the operational cost of digital banking. In the long term, it will optimize bank income margins. It can expand bank cooperation with economic agents regarding fees and transaction fees for digital banking services. 
The other side of this research is the findings that have implications for the government regarding the banking industry's mobile technology strategy to optimize its future performance. The government and banks cannot ignore the fact that there is a difference in the acceptance of understanding and behavior of digital financial services in urban and rural areas. The government can consider digital financial assistance based on a society's specific characteristics, such as age, income and education, and sites' distribution. It is intended so that the digital finance strategy's effectiveness is right on target to increase the ease of financial and economic access. Continuous digital financial literacy and risk management by banks and governments are needed to accelerate public understanding of the application of sound, precise, and safe digital banking. However, community economic growth is thrust through inclusive financial services. Complete and affordable digital financial services that facilitate financial services will undoubtedly encourage people to use them.

For further research, we can simultaneously compare digital finance performance through financial inclusion from three perspectives: banks, non-bank financial services, and the user community. Using a mixed method that juxtaposes banking data with digital finance user response data is a promising opportunity for better mapping digital finance's role in financial inclusion and economic growth. It provides a complete picture of digital finance's influence on financial inclusion in urban and rural areas.

\section{REFERENCES}

Ahmad, A. A., Green, C., \& Jiang, F. (2020). Mobile Money, Financial Inclusion and Development: A Review Concerning African Experience. Journal of Economic Survey, 34(4), 753-792. https://doi.org/10.1111/joes.12372.

Agyekum, F., Locke, S., \& Hewa, N. W. (2016). Financial Inclusion and Digital Financial Services: Empirical evidence from Ghana. MPRA Paper No. 82885.

Bank Indonesia. (2016). Digital Financial Inclusion in Indonesia. Bank Indonesia. Jakarta

David-West, O., Adetunji, O., Ajai, O, Aluko, T., Iheanachor, N., Iyoha, F., Kelikume, I., Muritala, O., Nwagwu, I., Salami, A., Taiwo, I., \& Umukoro, I. (2018). Digital Financial Services in Nigeria: State of The Market Report. Lagos Business School, Pan-Atlantic University. Retrieved from https://www.researchgate.net

Dabla-Noris, E., Ji, Y., Townsend, R., \& Filiz, D.U. (2015). Identifying to Financial Inclusion and Their Impact n GDP and Inequity: Structural Framework for Policy. International Monetary Fund, No.15/22. International Monetary Fund. Washington DC.

Donovan, K. (2011). Mobile Money for Financial Inclusion. World Bank. Washington DC.

Gas, S. A. (2019). Mobile Money, Cashless Society and Financial Inclusion: Case Study on Somalia and Kenya. Retrieved from https://ssrn.com/abstract=3348257.

Gabor, D., \& Brooks, S. (2017). Digital Revolution in Financial Inclusion: International Development in The FinTech Era. New Political Economy, 22(4), 423-436. https:// doi.org/10.1080/13563467.2017.1259298

Gomber, P., Alexander, J. K., \& Siering, M. (2017). Digital Finance and FinTech: Current 
Research and Future Research Directions. Journal of Business Economics, 87, 537580. https://doi.org/10.1007/s11573-017-0852-x.

GPFI. (2011). The First G20 Global Partnership For Financial Inclusion ( GPFI ) Forum. Retrieved from http://www.gpfi.org.

Honohan, P., \& Beck, T. (2007). Making Finance Work for Africa. World Bank. Washington DC.

Salam Dz, A. (2018). Inklusi Keuangan Perbankan Syariah Berbasis Digital-Banking: Optimalisasi dan Tantangan. Al-Amwal: Jurnal Kajian Ekonomi dan Perbankan Syariah, 10(1), 63-80.

Kithinji, E. (2017). Effect of Digital Banking Strategy on Financial Inclusion Among Commercial Bank in Kenya. (Unpublished Thesis). University of Nairobi, Kenya.

Chavan, A. L., Arora, S., \& Koppula, P. (2009). How Mobile Money can Drive Financial Inclusion for Women at the Bottom of the Pyramid (BOP) in Indian Urban Centers. Proceeding HCI International 2009. https://doi.org/10.1007/978-3-642-02767-3_53.

Li, J., Wu., Y., \& Xiao, J. J. (2020). The Impact of Digital Finance on Household Consumption: Evidence from China. Economics Modelling, 86, 317-326. https:// doi.org/10.1016/j.econmod.2019.09.027.

Mago, S., \& Chitokwindo, S. (2014). The Impact of Mobile Banking on Financial Inclusion in Zimbabwe. Mediterranean Journal of Social Sciences, 5(9), 221-230. https://doi.org/10.5901/mjss.2014.v5n9p221

Ozil, P. K. (2018). Impact of Digital Finance on Financial Inclusion and Stability. Borsa Istanbul Review, 18(4), 329-340. https://doi.org/10.1016/j.bir.2017.12.003.

Peruta, M. D. (2015). Mobile Money Adoption and Financial Inclusion Objective: A Macroeconomic Approach through a Cluster Analysis, GREDEG Working Paper No. 2015-49. Retrieved from http://www.gredeg.cnrs.fr

Raj, S. D. (2015). Financial Inclusiveness: The Role of Mobile Money and Digital Financial Services. Socrates, 3(1), 95-112.

Senyo, P. K., \& Osabutey, E. L. C. (2020). Unearthing Antecedents to Financial Inclusion Through FinTech Innovations. Technovation, 98, 102155. https://oi.org/10.1016/j. technovation.2020.102155.

Sahay, R., Cihak, M., N’Diaye, P., Barajas, A., Mitra, S., Kyobe, A., Nian Y. M., \& Reza S.Y. (2015). Financial Inclusion: Can it Meet Multiple Macroeconomics Goals? International Monetary Fund, No.15/17. International Monetary Fund. Washington DC.

Son, T. H., Liem, N. T., \& Khong, N.V. (2020). Mobile Money, Financial Inclusion and Digital Payments: The Case of Vietnam. International Journal of Financial Research, 11(1), 417-424. https://doi.org/10.5430/ijfr.v11n1p417/

Singh, A. S., Venkataramani, B., \& Ambarkhane, D. (2014). Role of Mobile Banking in Financial Inclusion. Retrieved from https://ssrn.com/abstract-2485777.

Warjiyo, P. (2021). Outlook Ekonomi 2021 dan Bauran Kebijakan Bank Indonesia Untuk Percepatan Pemulihan Ekonomi Nasional. Bank Indonesia. Jakarta.

World Bank Group. (2016). FinTech and Financial Inclusion. World Bank. Washington DC. 